\title{
A Rare Case: Granular Cell Tumor of the Tongue
}

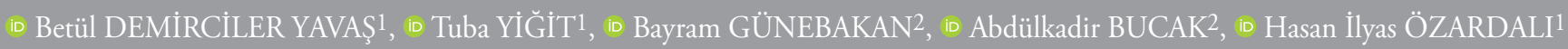

${ }^{1}$ Afyon Kocatepe Univertsity Faculty of Medicine, Department of Medical Pathology, Afyonkarahisar, Turkey

${ }^{2}$ Afyon Kocatepe Univertsity Faculty of Medicine, Department of Ear Nose Throat, Afyonkarahisar, Turkey

\begin{abstract}
Granular cell tumors (GCT) are rare neoplasms and their diagnosis is mainly based on histopathologic examination of biopsies. Granular cell tumor is a neoplasm that has been reported in a variety of organs, including the extremities, head and neck skin, oral cavity and gastrointestinal tract. The cell of origin in GCT is controversial. In this article, we present a case of granular cell tumor of the tongue at the 49-year-old female patient with the knowledge of the literature.
\end{abstract}

Keywords: Granular cell tumor, tongue, immunohistochemistry

\section{Introduction}

Granular cell tumor (GCT) is a rarely seen lesion that mostly displays a benign course. It constitutes less than $1 \%$ of head and neck tumors (1). 1-2\% of the cases show a malignant course (24). GCT is typically located in the extremities and head-neck skin, oral cavity and gastrointestinal system (5). Although it can be seen at any age, it is more common in the $4^{\text {th }}$ and $5^{\text {th }}$ decades. It is thought that peripheral nerves originate from "schwann" cells (2). Its benign forms can be treated by local excision (6).

\section{Case Report}

The lesion of a 49-year-old female patient with a complaint of cream-colored discomforting swelling (Figure 1), which had been growing on the left side of the tongue midline for 3 years, was excised. In the macroscopic examination, two pieces of light yellow - cream colored tissue measuring $0.8 \times 0.5 \times 0.4 \mathrm{~cm}$ and $0.5 \times 0.5 \times 0.3$ $\mathrm{cm}$ were observed. Microscopic examination of hematoxylin-eosin staining revealed monomorphic, polygonal shaped cells with large, granular, eosinophilic cytoplasm and small nucleus with central or eccentric localization, which were unencapsulated in the form of nests between muscle fibers and showing infiltrative spread pattern (Figure 2, 3). Mitosis, pleomorphism and necrosis were not observed in these cells. In the immunohistochemical examinations, S100 (Figure 4), NSE (Figure 5), CD68 (Figure 6), inhibina (Figure 7) and vimentin (Figure 8) were detected to be positive. Ki-67 proliferation index was found to be $2 \%$ (Figure 9). Based on these findings, the patient was diagnosed with granular cell tumor.

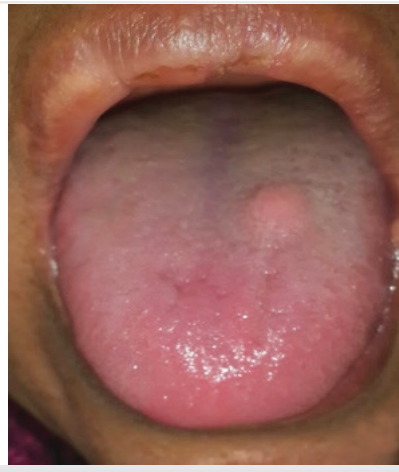

Figure 1. Gray-yellow colored swelling on the left side of the tongue midline

Address for Correspondence: Betül DEMIRCILER YAVAŞ, Afyon Kocatepe Univertsity Faculty of Medicine, 


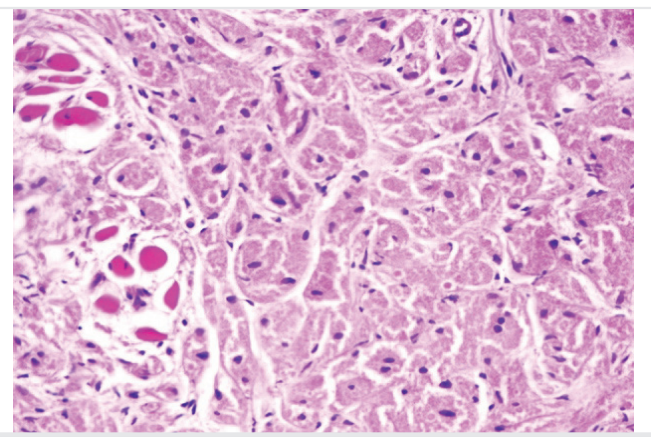

Figure 2. Monomorphic, polygonal shaped cells with large, granular, eosinophilic cytoplasm and small nucleus with central or eccentric localization, which were trabecular and in the form of nests between the muscle fibers ( $x 200, H-E)$

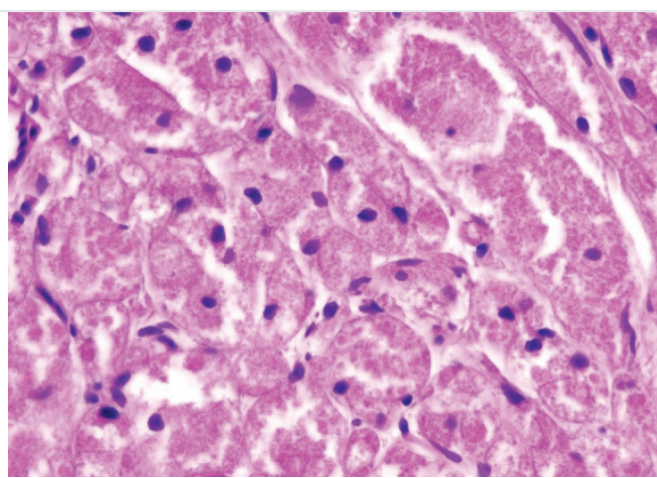

Figure 3. Monomorphic, polygonal shaped cells with fine granular, eosinophilic large cytoplasm and small nucleus with central or eccentric localization (x400, H-E)

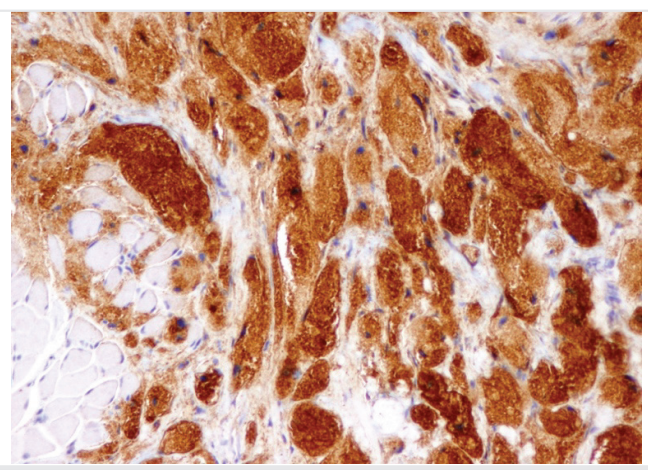

Figure 4. Cytoplasmic staining with S100 (x200, S100)

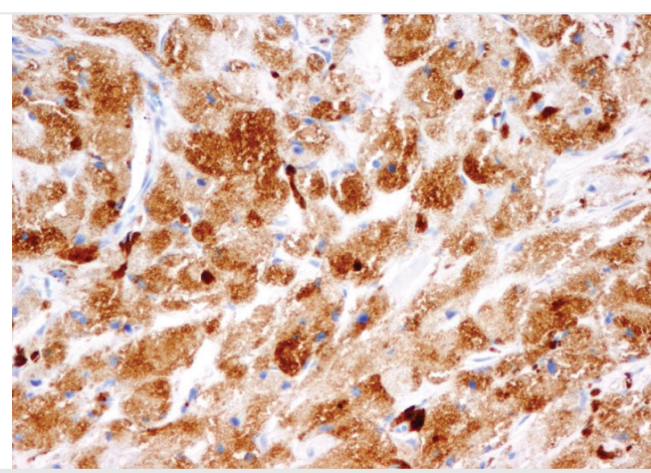

Figure 5. Cytoplasmic staining with NSE (x200, NSE)

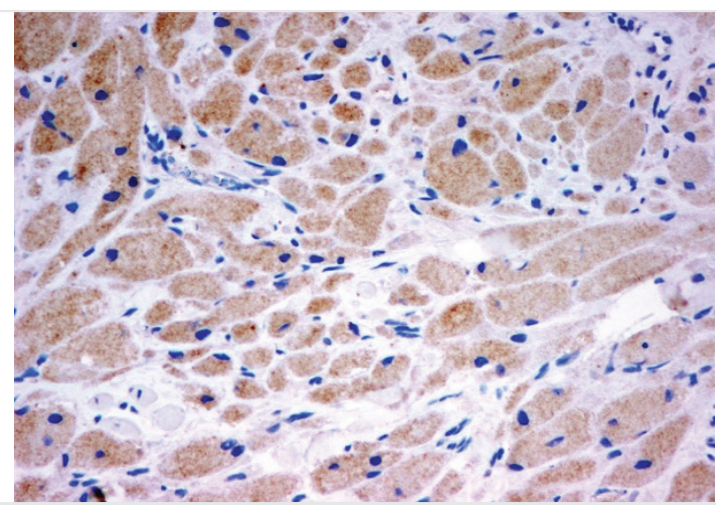

Figure 6. Cytoplasmic staining with CD68 (x200, CD68)

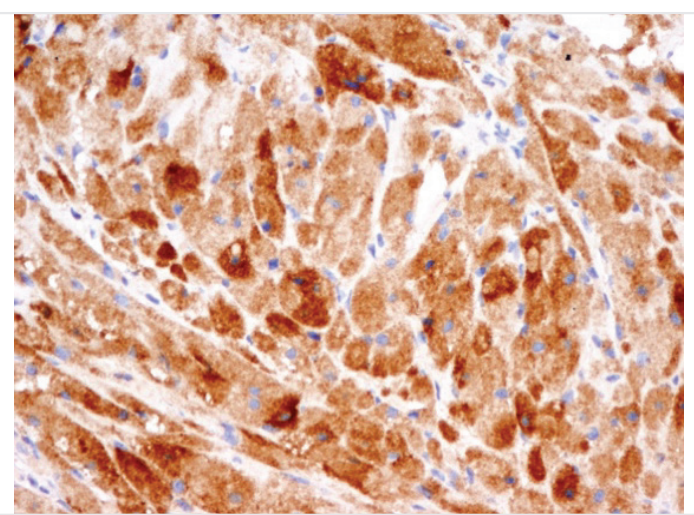

Figure 7. Cytoplasmic staining with Inhibina (x200, Inhibin a)

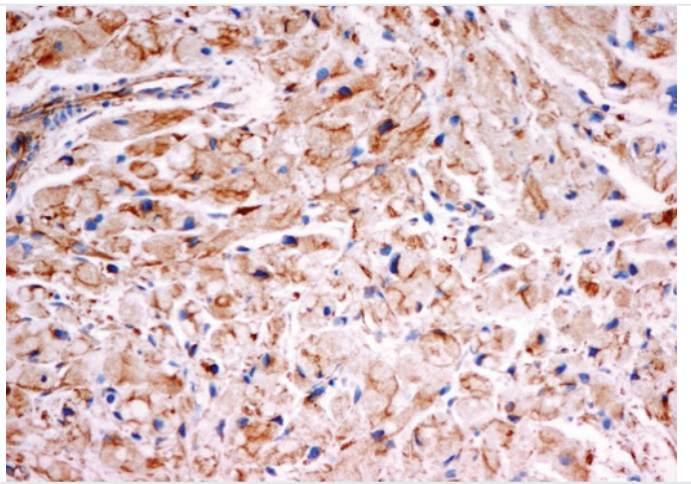

Figure 8. Cytoplasmic staining with vimentin ( $x 200$, Vimentin)

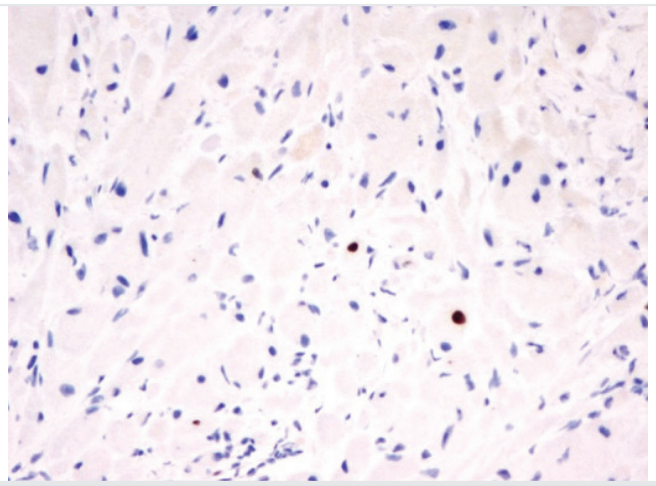

Figure 9. Nuclear staining with ki-67, proliferation index $2 \%$ (x200, ki-67) 


\section{Discussion}

GCT accounts for less than 1\% of all head and neck tumors. $50 \%$ of GHTs in the head and neck are located in the oral cavity. It is predominantly seen in women in the 4th and 5 th decades $(1,2,5,8,9)$. It was first reported by Weber in 1854 and then by Abrikossoff in 1926. It is called granular cell myoblastoma because it is thought to be of striated muscle origin (7).

Very different views have been made regarding the cells from which GCT originate due to its different cell histopathology. It is thought to develop from skeletal muscle, histiocytes, fibroblasts, nerve sheath cells, neuroendocrine cells and differentiated mesenchymal cells (2). Recent immunohistochemical and electronmicroscopic studies have shown that the origin of these tumors is "schwann "cells $(1,2,9)$. While GCT is immunohistochemically stained with S100, p75, NSE and CD68, inhibina, and vimentin, it is not stained with

smooth muscle actin (SMA), epithelial membrane antigen, HHF35, synaptophysin, chromogranin, progesterone, androgen, estrogen, carcinoembryonic antigen (CEA), and PanCK $(2,3,9)$. In our case, S100, NSE, CD68, vimentin, and inhibin alpha were positive. Ki-67 proliferation index was found to be $2 \%$. PanCK, CEA, and SMA did not react immunohistochemically.

Although the majority of GCTs are benign, they have been reported to display a malignant behavior at a lower rate. GCT's being macroscopically well-demarcated, lack of necrosis and degeneration areas, and its slow growth suggests that it is benign (4). In general, 6 criteria were determined for malignancy. These include being spindle cells, large nucleolus-bearing vesicular nucleus, increased mitosis (>2 mitosis/10-200Xdomain), increased nucleus/cytoplasm ratio, and the existence of pleomorphism and necrosis. The presence of 3 or more of these criteria supports the diagnosis of malignant GCT. If one or two of these criteria are present, a diagnosis of atypical granular cell tumor is made. In addition, p53 expression and high ki-67 index have been reported to be associated with aggressive progression in recent years. $1-2 \%$ of the cases have malignant course $(4,9,10)$. In our case, none of the criteria for malignancy was found, and the ki-67 index was 2\%.

The lesions with which GCT is most commonly confused clinically and macroscopically are other soft tissue tumors and traumatic fibromas $(4,9)$.

Its treatment is surgical excision. It recurs approximately at the rate of $10 \%$ after it is completely excised. However, when excision cannot be performed completely, regular clinical radiological follow-up is required. In malignant patients, its effect is not known exactly and radiotherapy and chemotherapy are administered $(7,9)$. If recurrence occurs, there are opinions suggesting the application of radiation after surgery $(1,7,9)$.
In conclusion, GCT is a very rare tumor that can be confused with different lesions clinically and macroscopically, for which histopathological evaluation is very important.

\section{Ethics}

Informed Consent: Written informed consent was obtained from the patient who participated in this case.

Peer-review: Externally peer-reviewed.

\section{Author Contributions}

Concept: B.D.Y., Design: B.D.Y., Data Collection and/ or Processing: B.D.Y, T.Y., A.B., B.G., Analysis and/or Interpretation: B.D.Y., A.B, Literature Review: B.D.Y., H.İ.Ö., Writing: B.D.Y.

Conflict of Interest: No conflict of interest was declared by the authors.

Financial Disclosure: The authors declared that this case has received no financial support.

\section{References}

1. Thompson LD, Wenig BM. Oral Cavity. Diagnostic Pathology: Head and Neck $2^{\text {nd }}$ Edition. Altona: Elsevier Health Sciences 2016;332-438.

2. Rajagopal MD, Gochhait D, Shanmugan D, Barwad AW. Granular Cell Tumor of Cecum: A Common Tumor in a Rare Site with Diagnostic Challenge. Rare tumors 2017;9:6420.

3. Jia X, Chen C, Chen L, Yu C, Kondo T. Large malignant granular cell tumor with suprascapular nerve and brachial plexus invasion: A case report and literature review. Medicine (Baltimore) 2017;96:e8531.

4. Diniz G, Vuruşkaner H, Çelebiler I, Ortaç R, Aktaş S, Özener V. On üç yaşında bir kız çocukta, uyluk yumuşak dokusunda lokalize granüler hücreli tümör olgusu. Türkiye Ekopatoloji Dergisi 2005;11:33-6.

5. Park JY, Kwon WJ, Park BW, Cho EB, Park EJ, Kim KH, et al. Congenital Non-Neural Granular Cell Tumor Mimicking Nevus Lipomatosus Superficialis. Ann Dermatol 2017;29:776-8.

6. Perçinel S, Savaş B, Yilmaz G, Erinanç H, Küpana Ayva Ş, Bektaş M, et al. Granular cell tumor of the esophagus: Three case reports and review of the literature. Turk J Gastroenterol 2008;19:184-8.

7. Bhati AS, Tyagi A, Tyagi SK. Recurrent granular cell tumor: A case report and review of literature. J Spin Surg 2017;3:484-8.

8. Gökçe H, Durak MG, Akın MM, Canda T, Balci P, Sevinç Aİ. Granular cell tumor of the breast: A case report. Eur J Breast Health 2011;7:230-3.

9. Doğusoy GB, Ağız Boşluğu ve Orofarenks. In: Sarığlu S, editor. Baş Boyun Patolojisi. İzmir: O’ TIP Kitabevi; 2014.p.65-87.

10. Hülagü S, Sentürk O, Aygün C, Gürbüz Y, Kocaman O, Celebi A, et. al. Granular cell tumor of esophagus removed with endoscopic submucosal dissection. Turk J Gastroenterol 2007;18:188-91. 